Jurnal Keperawatan Silampari

Volume 5, Nomor 1, Desember 2021

e-ISSN: 2581-1975

p-ISSN: 2597-7482

DOI: https://doi.org/10.31539/jks.v5i1.3058

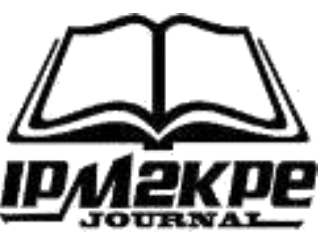

\title{
HUBUNGAN AKTIVITAS FISIK HARIAN DENGAN KUALITAS HIDUP PENYINTAS KANKER PAYUDARA
}

\author{
Risna Meliyani ${ }^{1}$, Wirsma Arif Harahap ${ }^{2}$, Elvi Oktarina ${ }^{3}$ \\ Universitas Andalas $1,2,3$ \\ risnameliyani63@gmail.com ${ }^{1}$
}

\begin{abstract}
ABSTRAK
Penelitian ini bertujuan untuk mengatahui hubungan aktivitas fisik harian dengan kualitas hidup penyintas kanker payudara. Desain penelitian yang digunakan adalah korelatif dengan pendekatan cross-sectional. Hasil penelitian menunjukkan 53,9\% responden berusia > 60 tahun, 50,6\% responden memiliki pendidikan tinggi, 61,8\% responden tidak bekerja, 49,1\% responden stadium IIIA, 55,1\% responden memiliki aktivitas fisik harian sedang dan $73,0 \%$ responden memiliki kualitas hidup sedang. Sebagian besar responden memiliki aktivitas fisik sedang 55,1\%, dengan sebagian besar kualitas hidup sedang 73,0\%. Hasil analisis bivariat didapatkan bahwa ( $p$-value=0,034). Simpulan, ada hubungan aktivitas fisik harian dengan kualitas hidup pada penyintas kanker payudara di RSUP Dr. M. Djamil Padang.
\end{abstract}

Kata Kunci: Aktivitas Fisik, Kanker Payudara, Kualitas Hidup

\section{ABSTRACT}

This study aims to determine the relationship of daily physical activity with the quality of life of breast cancer survivors. The research design used is correlative with a crosssectional approach. The results showed 53.9\% of respondents aged $>60$ years, $50.6 \%$ of respondents had higher education, $61.8 \%$ of respondents did not work, $49.1 \%$ of stage IIIA respondents, $55.1 \%$ of respondents had moderate daily physical activity, and 73,0\% of respondents have a reasonable quality of life. Most respondents have moderate physical activity, 55.1\%, with most of the quality of life being 73.0\%. The results of the bivariate analysis showed that ( $p$-value $=0.034)$. In conclusion, there is a relationship between daily physical activity and the quality of life of breast cancer survivors at RSUP Dr. M. Djamil Padang.

Keywords: Physical Activity, Breast Cancer, Quality of Life

\section{PENDAHULUAN}

Kanker payudara adalah salah satu jenis kanker yang umum terjadi pada wanita yang disebabkan adanya tumor ganas yang tumbuh didalam jaringan payudara (WHO, 2018). Kanker payudara merupakan jenis kanker yang paling banyak terjadi mencapai $58.256(16,7 \%)$ kasus dari total 348.809 kasus setiap tahunnya (WHO, 2018). Menurut american cancer society (2018) menyatakan bahwa perempuan 100 kali lebih berisiko mengalami kanker payudara di bandingkan pria, risiko dari timbulnya kanker payudara meningkat seiring bertambahnya usia dimana 95\% dari kasus baru dan 97\% kematian akibat kanker payudara terjadi pada wanita berusia 40 tahun keatas, tingkat 
kelangsungan hidup kanker payudara diperkirakan selama 5 tahun hingga 10 tahun (American Cancer Society, 2018).

Di Asia Tenggara didapatkan bahwa prevalensi kanker payudara sebesar 35,46\% artinya 1 dari 3 kasus di Asia meninggal akibat kanker payudara, mortalitas/angka kematian akibat kanker payudara di dunia ialah sebesar 521.900 kematian. Berdasarkan data Riskesdas (2018) bahwa kanker payudara di Indonesia merupakan penyakit dengan prevalensi kedua tertinggi setelah kanker serviks dengan angka kejadian yang masih cukup tinggi yaitu sebesar 4,8 juta kasus pada tahun 2018 (Kemenkes RI, 2018). Berdasarkan data yang di paparkan Kementerian Kesehatan Republik Indonesia (2018) per tanggal 31 Januari 2019 mengungkapkan bahwa kasus tertinggi pada perempuan merupakan kanker payudara pada tahun 2013 yaitu 1,4/1000 penduduk meningkat pada tahun 2018 menjadi 1,79/1000 penduduk (Kemenkes RI, 2019). Sumatera Barat menduduki posisi kedua tertinggi penderita kanker payudara setelah Yogyakarta yaitu 0,9\% dengan estimasi jumlah 479 Kasus pada tahun 2019 (Kemenkes RI, 2018).

Faktor resiko yang juga diketahui dapat memicu terjadinya kanker payudara adalah faktor hormonal/reproduksi, faktor intrinsik dan faktor yang diperoleh. Penelitian Neumayer \& Viscusi (2018) mengatakan bahwa perempuan memiliki risiko seumur hidup $12 \%$ terkena kanker payudara, risiko individu dipengaruhi oleh berbagai faktor seperti riwayat keluarga, riwayat reproduksi, gaya hidup, dan lingkungan. Kemudian kanker payudara juga memiliki faktor risiko yang dapat dicegah atau tidak dapat dicegah. Risiko yang tidak dapat dicegah (di luar kendali) faktor termasuk riwayat kesehatan, riwayat keluarga dan usia. Faktor risiko yang dapat dicegah termasuk konsumsi alkohol, aktivitas fisik dan berat badan.

Salah satu faktor resiko kekambuhan yang dapat dicegah adalah aktivitas fisik harian yaitu gerakan tubuh yang dihasilkan oleh otot-otot rangka yang membutuhkan pengeluaran energi (WHO, 2018). Aktivitas fisik harian mempunyai peran yang penting terhadap pencegahan, pengobatan, dan pemulihan beberapa penyakit yang merupakan sasaran yang penting bagi penderita kanker (Browall et al., 2018). Menurut Hodges \& Winstanley (2018) mengatakan bahwa pasien dengan kanker payudara sejak dua tahun setelah menjalani operasi, semua tingkat aktivitas (total, pekerjaan, olahraga dan rumah tangga) masih secara signifikan lebih rendah dibandingkan dengan nilai sebelum operasi.

Salah satu efek negatif yang ditimbulkan setelah pengobatan kanker payudara adalah gangguan kualitas hidup. Kualitas hidup merupakan perasaan puas atau bahagia karena dapat melakukan kehidupan sehari - hari secara mandiri (Joe \& Darmayasa, 2019). Salah satu bentuk kualitas hidup pada pasien kanker payudara yang terjadi seperti stadium kanker. Kualitas hidup mencangkup beberapa aspek fisik, psikologis, sosial dan lingkungan. Kesehatan fisik mencakup kesehatan umum, nyeri, energi dan vitalitas, aktivitas seksual, tidur, istirahat. Kesejahteraan psikologis mencakup cara berpikir, belajar, memori, konsentrasi dan emosi.

Fontes et al., (2018) menggambarkan kualitas hidup pasien kanker payudara menurun pada dimensi peran, emosional, kognitif dan sosial, sedangkan gejala yang dirasakan oleh kanker payudara adalah kelelahan, nausea, dyspnoea, insomnia, konstipasi, diare dan kehilangan nafsu makan. Gejala berupa kecemasan, nyeri, kelelahan, dan gejala menopause berdampak pada aktivitas hidup keseharian pasien dan selanjutnya kualitas hidupnya (Ribeiro et al., 2020). 
Penelitian yang dilakukan Shen et al., (2020) didapatkan skor kualitas hidup yang dianalisis secara deskriptif bahwa dari 63 pasien kanker payudara 41 orang $(65,1 \%)$, kualitas hidup baik, 22 orang (34,9\%) dengan kualitas hidup kurang baik.

Penyintas kanker payudara dapat meningkatkan kualitas hidup dengan cara alami dan menjaga kesehatan dan mencegah penyakit dengan aktivitas fisik harian (Eyl, et al. 2018). Hasil penelitian Maridaki (2020) aktivitas fisik harian mempunyai peran penting dalam meningkatkan kualitas hidup pasien. Hasil penelitian oleh Robertson (2019) yang menunjukkan bahwa aktivitas fisik mempunyai peran penting dalam meningkatkan kualitas hidup pasien.

Berdasarkan data dari rekam medis RSUP Dr. M. Djamil Padang pada tahun 2019-2020 pasien kanker payudara yang datang berobat mencapai 219 pasien kanker payudara. Tahun 2020 didapatkan jumlah pasien kanker payudara yaitu sebanyak 115 pasien. Studi pendahuluan yang dilakukan di ruang poli bedah RSUP DR.M.Djamil padang pada tanggal 17-18 April 2021 terdapat 5 penyintas kanker payudara yang datang berobat dengan berbagai keluhan, penyintas payudara yang datang rata-rata dimulai dengan stadium awal sampai stadium advance dan lama menderita selama kurang lebih 3 tahun.

Kemudian peneliti menemukan bahwa beberapa penyintas kanker payudara yang sudah mulai penerimaan diri dan sudah beradaptasi dengan kondisinya tatapi masih merasakan beberapa keluhan pada fisik seperti kelelahan karena efek dari pengobatan, keterbatasan gerak, namun diantara penyintas kanker payudara mengatakan masih dapat melakukan aktivitas fisik harian seperti melakukan pekerjaan rumah dengan mencuci baju dan piring, menyapu, menyetrika, menyapu halaman rumah, dan masih dapat melakukan aktivitas pekerjaan di luar seperti mengajar, berdagang, masih dapat naik turun mobil dan sedikit membatasai untuk naik turun tangga, aktivitas olahraga yang berat tidak pernah dilakukan lagi hanya seperti jalan santai di pagi hari kurang lebih selama 10 menit.

Namun ada juga yang mengatakan merasa terganggu dalam menyelesaikan tugas dan pekerjaan nya dikarenakan setelah pengobatan terkadang lemas, dan sedikit membatasai aktivitas di luar rumah, beberapa diantaranya juga mengatakan kadang mual, sulit tidur, susah BAB dan kehilangan nafsu makan setelah tindakan, kemudian pada masalah psikologis peneliti menemukan bahwa diantara penyintas kanker payudara mengalami tekanan seperti cemas, tidak fokus terhadap pemikiran nya sendiri, beranggapan bahwa hidupnya akan segera berakhir dan memiliki kualitas hidup yang buruk. Penelitian ini berfokus pada hubungan aktivitas fisik harian dengan kualitas hidup penyintas kanker payudara.

\section{METODE PENELITIAN}

Desain penelitian yang digunakan adalah korelatif dengan pendekatan cross sectional. Sampel penelitian adalah penyintas kanker payudara di poli bedah RSUP DR. M. Djamil Padang sebanyak 89 orang. Teknik pengambilan sampel menggunakan teknik purposive sampling. Kriteria inklusi penelitian antara lain; 1) Dapat berkomunikasi dengan baik; 2) Mampu membaca dan menulis; 3) Telah terdiagnosis kanker payudara selama lebih dari 6 bulan; 4) Penyintas kanker payudara dengan stadium dini 0-III A; 5) Penyintas kanker payudara yang mendapatkan pengobatan konvensional, mastectomy, kemoterapi, radioterapi, terapi hormonal dan targeting terapi. Sedangkan kriteria eksklusi penelitian antara lain; 1) Disabilty (Keterbatasan khusus); 2) Penyintas kanker payudara yang menolak untuk dijadikan sampel; 3) 
Penyintas kanker payudara dengan gangguan mental; 4) Penyintas kanker payudara dengan gangguan musculoskeletal, 5) Penyintas kanker payudara dengan komplikasi.

Instrumen penelitian yang digunakan adalah kuesioner. Kuesioner kualitas hidup berdasarkan Questionnaire WHOQOL-BREF, sedangkan aktivitas fisik menggunakan International Physical Activity Questionnair-Short form. Penelitian dimulai dengan meminta persetujuan responden bahwa bersedia untuk menjadi subjek penelitian dengan menandatangani pernyataan persetujuan bersedia menjadi subjek penelitian. Teknik pengumpulan data dengan cara wawancara. Data dianalisis menggunakan uji statistik chi square.

\section{HASIL PENELITIAN}

Tabel. 1

Gambaran Karakteristik, Kualitas Hidup dan Aktivitas Fisik Harian

\begin{tabular}{lcc}
\hline \multicolumn{1}{c}{ Karakteristik } & Frekuensi & Persentase \\
\hline Usia & & \\
Dewasa & 41 & 46,1 \\
Lansia & 48 & 53,9 \\
\hline Pendidikan & & \\
Rendah & 44 & 49,4 \\
Tinggi & 45 & 50,6 \\
\hline Pekerjaan & & \\
Bekerja & 34 & 38,2 \\
Tidak Bekerja & 55 & 61,8 \\
\hline Stadium & & \\
Stadium II A & 37 & 41,6 \\
Stadium II B & 8 & 9,0 \\
Stadium III A & 44 & 49,4 \\
\hline
\end{tabular}

Berdasarkan tabel 1 diketahui 53,9\% responden berusia > 60 tahun, 50,6\% responden memiliki pendidikan tinggi, 61,8\% responden tidak bekerja, 49,1\% responden stadium IIIA, 55,1\% responden memiliki aktivitas fisik harian sedang dan $73,0 \%$ responden memiliki kualitas hidup sedang.

Tabel. 2

Hubungan Aktivitas Fisik Harian dengan Kualitas Hidup Penyintas Kanker Payudara

\begin{tabular}{|c|c|c|c|c|c|c|c|c|c|}
\hline \multirow{3}{*}{ Aktivitas Fisik } & \multicolumn{6}{|c|}{ Kualitas Hidup } & \multirow{2}{*}{\multicolumn{2}{|c|}{ Total }} & \multirow{3}{*}{$\begin{array}{c}p- \\
\text { value }\end{array}$} \\
\hline & \multicolumn{2}{|c|}{ Buruk } & \multicolumn{2}{|c|}{ Sedang } & \multicolumn{2}{|c|}{ Baik } & & & \\
\hline & $\mathrm{F}$ & $\%$ & $\mathrm{f}$ & $\%$ & $\mathrm{~F}$ & $\%$ & $f$ & $\%$ & \\
\hline Ringan & 12 & 32,4 & 24 & 64,9 & 1 & 2,7 & 37 & 100,0 & \\
\hline Sedang & 6 & 12,2 & 40 & 81,6 & 3 & 6,2 & 49 & 100,0 & 0,034 \\
\hline Berat & 1 & 33,3 & 1 & 33,3 & 1 & 33,3 & 3 & 100,0 & \\
\hline Total & 19 & 21,4 & 65 & 73,0 & 5 & 5,6 & 89 & 100,0 & \\
\hline
\end{tabular}

Berdasarkan tabel 2 menunjukkan kualitas hidup penyintas kanker payudara berhubungan dengan aktivitas fisik dengan nilai-p 0,034 (p-value $<0,05$ ). 


\section{PEMBAHASAN}

Berdasarkan hasil uji statistik (chi-square) menunjukkan bahwa kualitas hidup penyintas kanker payudara berhubungan dengan aktivitas fisik harian. Masalah yang dirasakan oleh penderita kanker payudara diantaranya adalah lymphoedema, nyeri, kelelahan dan kualitas hidup (QoL) dan ini akan mengganggu terhadap kehidupan sehari hari seperti akan terjadi kecemasan, depresi, gangguan, tidur, kelelahan dan gejala gastrointestinal. Pada saat ini diperlukan perawatan atau intervensi untuk penanganan pada pasien kanker payudara dimana perawatan ini sangat dibutuhkan dan mampu mengurangi gejala yang dirasakan dan dapat meningkatkan kualitas hidup (Solehati et al., 2020; Rosen \& Potter, 2018).

Orang yang menderita kanker tidak hanya menderita secara fisik, tetapi juga bisa mempengaruhi psikologisnya seperti perasaan cemas, depresi dll. Hal tersebut dapat dihilangkan dengan olahraga. Apabila penderita kanker rutin berolahraga akan muncul manfaat yang sangat banyak antara lain mengurangi berat badan, menghilangkan depresi dan kelelahan otot, menambah massa otot, dan mental menjadi lebih sehat (Komite Nasional Penanggulangan Kanker Nasional, 2019).

Penderita kanker payudara juga mengalami perubahan-perubahan pada sistem dan fungsi tubuh yang dapat menimbulkan gangguan konsep diri, hampir semua penderita kanker payudara mengalami perubahan gambaran diri jika perubahan ini tidak terintegrasi dengan konsep diri maka kualitas hidup penderita akan semakin menurun (Joe \& Darmayasa, 2019).

Fontes et al., (2018) menggambarkan kualitas hidup pasien kanker payudara menurun pada dimensi peran, emosional, kognitif dan sosial, sedangkan gejala yang dirasakan oleh kanker payudara adalah kelelahan, nausea, dyspnoea, insomnia, konstipasi, diare dan kehilangan nafsu makan. Gejala berupa kecemasan, nyeri, kelelahan, dan gejala menopause berdampak pada aktivitas hidup keseharian pasien dan selanjutnya kualitas hidupnya (Ribeiro et al., 2020).

Hasil penelitian yang dilakukan Hananingrum et al., (2017) menunjukkan bahwa hasil penelitian aktifitas fisik pasien kanker serviks yang menjalani kemoterapi di RSUD Dr. Moewardi Surakarta sebagian besar malakukan aktifitas fisik sedang. Kualitas hidup pada pasien kanker serviks yang menjalani kemoterapi mayoritas tinggi. Ada hubungan aktivitas fisik dengan kualitas hidup pada pasien kanker serviks yang menjalani kemoterapi dengan $\mathrm{p}$ value $0,003<0,05$ dengan kekuatan hubungan sedang. Aktivitas fisik harian yaitu gerakan tubuh yang dihasilkan oleh otot-otot rangka yang membutuhkan pengeluaran energi, aktivitas ini mencakup aktivitas yang dilakukan di tempat kerja, aktivitas dalam keluarga/ rumah tangga, aktivitas selama dalam perjalanan dan aktivitas lain yang dilakukan untuk mengisi waktu senggang sehari-hari (WHO, 2018).

Hasil penelitian Menurut Browall et al., (2018) mengatakan bahwa pentingnya melakukan aktivitas fisik harian bagi pasien kanker payudara dengan kualitas hidup yang buruk. Secara fisiologis aktivitas fisik yang dilakukan dapat membuat peningkatan perubahan kardiorespirasi, peningkatan daya tahan otot, peningkatan oksidasi karbohidrat dan lemak, peningkatan kandungan myoglobin, menurunkan persentase lemak tubuh dan meningkatkan masa tubuh tanpa lemak, menurunkan tekanan darah dan membuat perubahan pada hormonal (Neumayer et al., 2018). Ada hubungan antara aktivitas fisik harian dengan kualitas hidup dalam penelitian ini menunjukkan bahwa semakin berat aktivitas fisik responden maka semakin baik kualitas hidup responden, begitu sebaliknya semakin ringan aktivitas fisik responden maka semakin buruk kualitas 
hidup responden tersebut. Responden memiliki semangat hidup yang lebih tinggi dan keinginan untuk hidup lebih baik serta adanya dukungan keluarga yang baik sehingga melakukan upaya untuk meningkatkan kualitas hidupnya yaitu melakukan aktivitas fisik yang baik, dengan aktivitas fisik yang baik maka kualitas hidup responden juga semakin baik.

Responden yang memiliki aktivitas fisik ringan namun memiliki kualitas hidup baik disebabkan adanya dukungan keluarga yang baik, responden tersebut mendapat motivasi dan dukungan dari keluarga. Sesuai dengan pendapat Nurjayanti (2019) menyatakan bahwa dukungan keluarga akan membuat pasien merasa nyaman, diperhatikan dan tidak sendirian dalam menjalani pengobatan kanker. Ini akan mempengaruhi kesehatan secara fisik dan psikologis. Semakin tinggi dukungan sosial yang diterima oleh pasien, maka semakin meningkat pula penerimaan diri dan kualitas hidupnya.

\section{SIMPULAN}

Ada hubungan antara aktivitas fisik dengan kualitas hidup penyintas kanker payudara.

\section{SARAN}

Diharapkan kepada rumah sakit agar lebih aktif memberikan penyuluhan atau konseling kepada pasien kanker payudara tentang faktor yang mempengaruhi kualitas hidup penderita kanker payudara sehingga dapat meningkatkan pengetahuan pasien dan dapat melakukan upaya peningkatan kualitas hidup. Mengadakan kegiatan seminarseminar motivasi bagi pasien yang menderita kanker dan keluarganya yang dapat memberikan semangat dalam menjalani perawatan dan pengobatan sehingga dapat meningkatkan kualitas hidupnya.

\section{DAFTAR PUSTAKA}

American Cancer Society. (2018). Breast Cancer Signs and Symptoms. Retrieved from https://www.cancer.org/cancer/breast-cancer/about/breast-cancer-signs-andsymptoms.html

Browall, M., Mijwel, S., Rundqvist, H., \& Wengström, Y. (2018). Physical Activity During and After Adjuvant Treatment for Breast Cancer: An Integrative Review of Women's Expericnces. Cancer Terapies. Retrieved from https://doi.org/10.1177/1534735416683807

Eyl, R. E., Xie, K., Koch-Gallenkamp, L., Brenner, H., \& Arndt, V. (2018). Quality of Life and Physical Activity in Long-Term ( $\geq 5$ Years Post-Diagnosis) Colorectal Cancer Survivors - Systematic Review. Health and Quality of Life Outcome, 16(1), 1-13. DOI: 10.1186/s12955-018-0934-7

Fontes, K. P., Veiga, D. F., Naldoni, A. C., \& Ferreira, L. M. (2018). Physical Activity, Functional Ability, and Quality of Life After Breast Cancer Surgery R. Journal of Plastic, Reconstructive \& Aesthetic Surgery, xxxx. Retrieved from https://doi.org/10.1016/j.bjps.2018.10.029

Hananingrum, R. (2017). Hubungan Aktivitas Fisik dengan Kualitas Hidup pada Pasien Kanker Serviks yang Menjalani Kemoterapi di RSUD Dr. Moewardi Surakarta. Universitas Muhammadiyah Surakarta. BSR https://eprints.ums.ac.id/eprint/53713 
Hodges, K., \& Winstanley, S. (2018). Effects of Optimism, Social Support, Fighting Spirit, Cancer Worry and Internal Health Locus of Control on Positive Affect in Cancer Survivors: A Path Analysis. Stress Health, 415, 408-415. https://doi.org/10.1002/smi.2471

Joe, A., \& Darmayasa, M. (2019). Kualitas Hidup pada Pasien Penderita Kanker Serviks di RSUP Sanglah Denpasar Periode Juni 2016 Hingga Januari 2017. Jurnal Keperawatan, 50(2), 350-356. DOI: 10.15562/medicina.v50i2.822

Kemenkes RI. (2018a). Hari Kanker Sedunia 2019. Jakarta. https://www.kemkes.go.id/article/view/19020100003/hari-kanker-sedunia2019.html

Kemenkes RI. (2018b). Riset Kesehatan Dasar Tahun 2018. Jakarta: Kemenkes RI

Komite Nasional Penanggulangan Kanker Nasional. (2019). Pedoman Nasional Pelayanan Kedokteran Kanker Payudara. Jakarta: Kemenkes RI

Maridaki, M., Papadopetraki, A., Karagianni, H., Koutsilieris, M., \& Philippou, A. (2020). The Assessment and Relationship Between Quality of Life and Physical Activity Levels in Greek Breast Cancer Female Patients under Chemotherapy. Sports, 8(3) https://doi.org/10.3390/sports 8030032

Neumayer, L., \& Viscusi, R. K. (2018). Assessment and Designation of Breast Cancer Stage. In The Breast (Fifth Edit). Elsevier Inc. https://doi.org/10.1016/B978-0323-35955-9.00037-4

Nurjayanti, I. (2019) Dukungan Keluarga pada Pasien Kanker Payudara dengan Kemoterapi. JK: Jurnal Keperawatan Jurnal Ilmiah Penelitian, 17(1), 13-19. https://digilib.stikesicme-jbg.ac.id/ojs/index.php/jip/article/view/465

Ribeiro, F. E., Palma, M. R., Silva, D. T. C., Tebar, W. R., Vanderlei, L. C. M., Fregonesi, C. E. P. T., \& Christofaro, D. G. D. (2020). Relationship of Anxiety and Depression Symptoms with the Different Domains of Physical Activity in Breast Cancer Survivors. Journal of Affective Disorders, 273, 210-214. https://doi.org/10.1016/j.jad.2020.03.110

Robertson, M. C., Lyons, E. J., Song, J., Cox-Martin, M., Li, Y., Green, C. E., \& BasenEngquist, K. M. (2019). Change in Physical Activity and Quality of Life in Endometrial Cancer Survivors Receiving a Physical Activity Intervention. Health Qual Life Outcomes, 17(1), 91. https://pubmed.ncbi.nlm.nih.gov/31133040/

Rosen, K., \& Potter, J. (2018). Participant Engagement in a Commercially Available App-Based Mindfulness Training Intervention Delivered to Women Diagnosed with Breast Cancer. Iproceedings, 4(2), e11907.https://doi.org/10.2196/11907

Shen, A., Qiang, W., Wang, Y., \& Chen, Y. (2020). Quality of Life Among Breast Cancer Survivors with Triple Negative Breast Cancer-Role of Hope, Self-Efficacy and Social Support. European Journal of Oncology Nursing, 46. https://doi.org/10.1016/j.ejon.2020.101771

Solehati, T., Napisah, P., Rahmawati, A., Nurhidayah, I \& Kosasih, C. E. (2020). Penatalaksanaan Keperawatan pada Pasien Kanker Payudara: Systematic Review. Jurnal Ilmiah Permas: Jurnal Ilmiah Stikes Kendal, 10(1), 71-82. https://journal.stikeskendal.ac.id/index.php/PSKM/article/view/672

WHO. (2018). Breast Cancer. Early Diagnosis and Screeaning. World Health Organization Westren Pasific Region. Retrieved from https://www/who.int/cancer/prevention/diagnosis-screaning/breast - cancer /en/Daiakses februari 2021 